\section{Improving Nitrogen Use Efficiency in Melon by Grafting}

\author{
Giuseppe Colla ${ }^{1}$, Carolina María Cardona Suárez, and \\ Mariateresa Cardarelli \\ Dipartimento di Geologia e Ingegneria Meccanica, Naturalistica e Idraulica \\ per il Territorio, Università della Tuscia, 01100 Viterbo, Italy
}

Youssef Rouphael

Department of Crop Production, Faculty of Agricultural Engineering and Veterinary Medicine, Lebanese University, Dekwaneh-El Maten, Lebanon

Additional index words. Cucumis melo, Cucurbita maxima $\times$ Cucurbita moschata, grafting, nitrate reductase activity, nitrogen use efficiency

\begin{abstract}
Identification of rootstocks capable of improving the nitrogen use efficiency (NUE) of the scion could reduce $\mathbf{N}$ fertilization and nitrate leaching; however, screening different graft combinations under field conditions can be costly and time-consuming. This study evaluated a rapid and economical methodology for screening of melon rootstocks for NUE. Two experiments were designed. In the first, melon plants (Cucumis melo $\mathrm{L}$. cv. Proteo) either ungrafted or grafted onto four commercial rootstocks: 'Dinero' and 'Jador' (Cucumis melo L.), 'P360', and 'PS1313' (Cucurbita maxima Duchesne $\times$ Cucurbita moschata Duchesne) grown in hydroponics were compared in terms of shoot dry biomass, leaf area, root-to-shoot ratio, SPAD index, shoot $\mathrm{N}$ uptake, and nitrate reductase (NR) activity at the early developmental stage in response to nitrate availability $(0.5,2.5,5,10$, or $15 \mathrm{mM}$ of $\left.\mathrm{NO}_{3}{ }^{-}\right)$. The second experiment was aimed to confirm whether the use of a selected rootstock with high NUE ('P360') could improve crop performance and NUE of grafted melon plants under field conditions. In the first experiment, carried out under greenhouse conditions, melon plants grafted onto 'Dinero', 'Jador', and 'P360' rootstocks needed 5.7, 5.2, and 6.1 $\mathrm{mM}$ of $\mathrm{NO}_{3}^{-}$, respectively, to reach half-maximum shoot dry weight, whereas plants grafted onto 'PS1313' rootstock and the control treatment (ungrafted plants) needed 9.1 and $13.1 \mathrm{~mm}$ of $\mathrm{NO}_{3}{ }^{-}$, respectively. Total leaf area, SPAD index, and shoot $\mathrm{N}$ uptake increased linearly and quadratically in response to an increase of the $N$ concentration in the nutrient solution. At $2.5 \mathrm{mM}$ of $\mathrm{NO}_{3}^{-}$, melon plants grafted onto both C. melo and Cucurbita maxima $\times$ Cucurbita moschata rootstocks had the highest NR activity, whereas no significant difference was observed at $10 \mathrm{~mm}$ of $\mathrm{NO}_{3}{ }^{-}$. In the second experiment, carried out under open field conditions, increasing the $\mathrm{N}$ fertilization rates from 0 to $120 \mathrm{~kg} \cdot \mathrm{ha}^{-1}$ increased the total and marketable yields of melon plants, whereas the NUE decreased. When averaged over $\mathbf{N}$ levels, the marketable yield, NUE, and $N$ uptake efficiency were higher by $9 \%, 11.8 \%$, and $16.3 \%$, respectively, in 'Proteo' grafted onto 'P360' than in ungrafted 'Proteo' plants.
\end{abstract}

Nitrate $\left(\mathrm{NO}_{3}^{-}\right)$is the principal nitrogen $(\mathrm{N})$ source for most crops and a large number of these, including vegetables, require large quantities of $\mathrm{NO}_{3}^{-}$fertilizer to attain maximal yields (Ruiz et al., 2006). Balancing the amount of $\mathrm{N}$ needed for optimum plant growth while minimizing the $\mathrm{NO}_{3}{ }^{-}$that is transported to ground and surface waters remains a major challenge for everyone attempting to understand and improve agricultural nutrient use efficiency (Dinnes et al., 2002). Moreover, the necessity to face soil fertility problems in crop production by a "low-input" approach re-

Received for publication 28 Jan. 2010. Accepted for publication $24 \mathrm{Feb} .2010$.

This work was supported by the Italian Ministry of University and Research (MIUR-PRIN 2007), Project "Vegetable grafting: biophysiological basis, effects on crop and product quality" (DM no. 1175 of 18 Sept. 2007).

We are grateful to Massimiliano Natali for the help in the data collection.

${ }^{1}$ To whom reprint requests should be addressed; e-mail giucolla@unitus.it.

ars of the same species in absorption, translocation, and use of mineral nutrients (Ahmad et al., 2001; Baligar and Fageria, 2001). Genotypic variations in NUE have been reported in different crops such as rice (Fageria and Baligar, 2003), maize (Machado and Fernandes, 2001), and tobacco (Ruiz et al., 2006) and it has recently been shown that one way of developing crop varieties with improved NUE is the identification of key elements that control $\mathrm{N}$ assimilation processes (Ruiz et al., 2006).

After plant selection, a challenge that arises is for the traits that make this cultivar capable of high NUE to be transferred to other cultivars with lower efficiency but with agriculturally high commercial value. One way to avoid or reduce losses in production caused by low NUE in high-yielding genotypes would be to graft them onto rootstocks capable of improving NUE of the scion. In the past, grafting was used widely with vegetable crops to limit the effects of soil pathogens (Lee, 1994), but the reasons for grafting as well as the kinds of vegetables grafted have increased dramatically over the years. Grafts were used to induce resistance against low and high temperatures (Rivero et al., 2003; Venema et al., 2008), to enhance nutrient uptake (Leonardi and Giuffrida, 2006; Ruiz et al., 1997), increase synthesis of endogenous hormones (Dong et al., 2008), improve water use efficiency (Rouphael et al., 2008a), reduce uptake of persistent organic pollutants from agricultural soils (Otani and Seike, 2007), improve alkalinity tolerance (Colla et al., 2010), raise salt and flooding tolerance (Colla et al., 2006a, 2006b; Yetisir et al., 2006), improve fruit quality (Proietti et al., 2008), and limit the negative effect of cadmium, boron, and copper toxicity (Arao et al., 2008; Edelstein et al., 2007; Rouphael et al., 2008b; Savvas et al., 2009). Nevertheless, few published data are available concerning the $\mathrm{N}$ efficiency in grafted vegetable crops (Pulgar et al., 2000; Ruiz and Romero, 1999). Ruiz and Romero (1999), studying N metabolism in grafted melon plants, observed that the use of certain rootstocks in squash enhanced $\mathrm{NO}_{3}{ }^{-}$ reduction and $\mathrm{N}$ use, defined as an increase in the content of organic $\mathrm{N}$ in leaf tissue, which ultimately boosted production. However, the response of grafted melon to $\mathrm{N}$ was investigated at one level of nitrate in the nutrient solution $\left(6 \mathrm{~mm}\right.$ of $\left.\mathrm{NO}_{3}\right)$, whereas information was lacking concerning the influence of different levels of nitrate on grafted melon crop performance.

Starting from these considerations, two experiments were carried out in the following order: 1) to select among commercial melon rootstocks for improved NUE through the measurement of crop traits (shoot dry biomass, leaf area, root-to-shoot ratio, SPAD index, shoot $\mathrm{N}$ uptake, and nitrate reductase activity) at early development stages in response to nitrate availability; and 2) to confirm whether the use of the selected rootstock could improve crop performance and NUE of grafted melon plants under open field conditions.

\section{Materials and Methods}

Expt. 1: Selection of commercial melon rootstocks with more advantageous nitrogen use efficiency traits

Plant material and growth conditions. The first experiment was conducted in 2009 in a 
$300-\mathrm{m}^{2}$ polyethylene greenhouse situated on the Experimental Farm of Tuscia University, Central Italy (lat. $42^{\circ} 25^{\prime} \mathrm{N}$, long. $12^{\circ} 08^{\prime} \mathrm{E}$, alt. $310 \mathrm{~m}$ above sea level). Cucumis melo L. cv. Proteo (Syngenta Seeds, Mariano Comense, Italy) was grafted onto the following commercial rootstocks: 'Dinero' (Cucumis melo L.; Syngenta Seeds), 'Jador' (Cucumis melo L.; Vilmorin, Funo di Argelato, Italy), 'P360' (Cucurbita maxima $\times$ Cucurbita moschata; Società Agricola Italiana Sementi, Cesena, Italy), and 'PS1313' (Cucurbita maxima $\times$ Cucurbita moschata; Peto Seeds, Ventura, CA) using the procedure of "cleft grafting" described by Lee (1994), whereas ungrafted cv. Proteo was used as a control. The two C. melo ('Dinero' and 'Jador') and the two pumpkins ('P360' and 'PS1313') were selected as the most representative commercial rootstocks used in Italy. Seeds of the hybrid 'Proteo' were sowed on 26 Jan. The $C$. melo and the Cucurbita rootstocks were sown $4 \mathrm{~d}$ later and $7 \mathrm{~d}$ earlier than the scion seeds, respectively. Randomized complete block design was used with treatments replicated three times.

Twenty-five treatments were compared, which were obtained by a factorial combination of five nitrate levels in the nutrient solution $\left(0.5,2.5,5,10\right.$, or $15 \mathrm{~mm}$ of $\left.\mathrm{NO}_{3}{ }^{-}\right)$and five grafting combinations (i.e., ungrafted plants or grafted in one of the previously referenced rootstocks). Each experimental unit consisted of 15 plants. Daily temperature was maintained between 20 and $30{ }^{\circ} \mathrm{C}$, night temperature was always higher than $16^{\circ} \mathrm{C}$, and relative humidity ranged between $55 \%$ and $85 \%$. Grafted and ungrafted melons were transplanted at the two true-leaf-stage on 1 Mar. into pots (14 $\mathrm{cm}$ in diameter, $12-\mathrm{cm}$ height) containing $1.5 \mathrm{~L}$ of perlite. The pots were placed on 16- $\mathrm{cm}$ wide and $5 \mathrm{~m}$-long troughs with $30 \mathrm{~cm}$ between pots. In each trough, an independent tank was provided to supply plants with nutrient solution. The nutrient solution was pumped and delivered at a rate of 2 $\mathrm{L} \cdot \mathrm{min}^{-1}$ at the top end of every bench and allowed to run slowly down the trough, whereas the excess solution was drained back to the tank for recirculation.

Nutrient solution management. The basic nutrient solution used was a modified Hoagland and Arnon formulation. All chemicals used were of analytical grade, and composition of the nutrient solution was: $1.0 \mathrm{~mm}$ phosphorus, $2.75 \mathrm{~mm}$ sulfur, $4.0 \mathrm{~mm}$ potassium, $1.25 \mathrm{~mm}$ magnesium, $20 \mu \mathrm{M}$ iron, $9 \mu \mathrm{M}$ manganese, $0.3 \mu \mathrm{M}$ copper, $1.6 \mu \mathrm{M}$ zinc, 20 $\mu \mathrm{M}$ boron, and $0.3 \mu \mathrm{M}$ molybdenum. Nitrate as $\mathrm{Ca}\left(\mathrm{NO}_{3}\right)_{2}$ was added to the solution to obtain the five nitrate levels, $0.5,2.5,5,10$, or $15 \mathrm{~mm}$, for grafted and ungrafted melon plants. Furthermore, to balance the calcium, 7.25, 6.25, 5.0, 2.5, and $0 \mathrm{~mm} \mathrm{CaSO}_{4}$ were added, respectively. The $\mathrm{pH}$ of the nutrient solution for all treatments was 6.0. All nutrient solutions were prepared using deionized water.

Data collection and analysis. In the last part of the growing cycle, a chlorophyll meter (SPAD-502; Minolta Corporation, Ltd., Osaka, Japan) was adopted to take dimensionless Soil Plant Analysis Development
(SPAD) values from the fully expanded functional leaves (the fourth from the apex). Measurements were made at a central point on the leaflet between the midrib and the leaf margin. The meter was shielded from direct sunlight by the operator during each measurement. Fifteen leaves were measured randomly per plot and averaged to a single SPAD value for each treatment.

At final harvest $45 \mathrm{~d}$ after transplanting (14 Apr.), eight plants per plot were separated into stems, leaves, and roots and their tissues were dried in a forced-air oven at $80{ }^{\circ} \mathrm{C}$ for $72 \mathrm{~h}$ for biomass determination. Shoot biomass was equal to the sum of aerial vegetative plant parts (leaves + stems). The rootto-shoot ratio was calculated by dividing root dry weight by the sum of leaf and stem dry weights. Total leaf area (LA) was measured with an electronic area meter (Delta-T Devices Ltd., Cambridge, UK). Shoot dry weight (SDW) was plotted as a function of the different nitrate concentrations. In accordance with the criteria of Gourley et al. (1994), these curves were described by nonlinear regression analysis using the following nonlinear equation:

$$
y=\frac{\alpha x}{\beta+x}
$$

where $x$ is the nitrate concentration (mM) and $y$ indicates the shoot dry weight (g/plant); $\alpha$ indicates maximum shoot dry weight, whereas $\beta$ represents the nitrate concentration at halfmaximum shoot dry weight.

Nitrate reductase was extracted from leaf tissues in all grafting combinations at two nitrate concentrations $(2.5$ and $10 \mathrm{~mm}$ of $\mathrm{NO}_{3}{ }^{-}$), which had been reduced to a fine powder in a mortar with liquid $\mathrm{N}$. The extraction buffer [50 mM Mops- $\mathrm{KOH}, \mathrm{pH}$ 7.8; $5 \mathrm{~mm} \mathrm{NaF} ; 1 \mu \mathrm{M} \mathrm{Na}_{2} \mathrm{MoO}_{4} ; 10 \mu \mathrm{M}$ FAD; $1 \mu \mathrm{M}$ leupeptin; $1 \mu \mathrm{M}$ microcystin; 0.2 $\mathrm{g} \cdot \mathrm{g}^{-1}$ fresh weight (FW) polyvinylpyrrolidone; 2 mм $\beta$-mercaptoethanol; 5 mм EDTA] was then added to the leaf tissue powder $(1 \mathrm{~mL} / 50$ $\mathrm{mg}$ FW) and the thawed homogenate centrifuged for $5 \mathrm{~min}$ at $12,000 \mathrm{~g}$. Nitrate reductase activity was then measured in the supernatants. The reaction mixtures consisted of buffer containing $50 \mathrm{~mm}$ Mops-KOH (pH 7.5), 1 $\mathrm{mm} \mathrm{NaF}, 10 \mathrm{~mm} \mathrm{KNO}, 0.17 \mathrm{~mm} \mathrm{NADH}$, and $5 \mathrm{~mm}$ EDTA. The reaction was stopped after $20 \mathrm{~min}$ by the addition of an equal volume of sulphanilamide $(1 \%$ in $3 \mathrm{~N} \mathrm{HCl})$ to the reaction mixture. N-napthyl-1-ethylene diamine dichlorohydrate $(0.02 \%)$ was added and the absorbance at $540 \mathrm{~nm}$ measured after centrifugation for $5 \mathrm{~min}$ at 12,000 $\mathrm{g}$ (Ferrario-Méry et al., 1997). The maximal catalytic activity of nitrate reductase was expressed as $\mu \mathrm{mol}$ $\mathrm{NO}_{2}{ }^{-} / \mathrm{g}$ of $\mathrm{FW} / \mathrm{h}$.

For the determination of total plant N, 0.5 $\mathrm{g}$ of the dried shoot tissue was used, and the $\mathrm{N}$ concentration was determined after mineralization with sulfuric acid by the "Regular Kjeldahl method" (Bremner, 1996). The results were expressed as $\mathrm{mg} \cdot \mathrm{g}^{-1}$ dry weight. The shoot $\mathrm{N}$ uptake was calculated by multiplying the shoot biomass (g/plant) by its $\mathrm{N}$ concentration $\mathrm{mg} \cdot \mathrm{g}^{-1}$ dry weight.
Expt. 2: Grafting to improve nitrogen use efficiency traits of melon under open field conditions

Plant material, crop management, experimental design, and nitrogen treatments. The second experiment was conducted in 2009 at the experimental farm of Tuscia University (lat. $42^{\circ} 25^{\prime} \mathrm{N}$, long. $12^{\circ} 08^{\prime} \mathrm{E}$, alt. $310 \mathrm{~m}$ above sea level). The soil was a sandy loam soil of volcanic origin (bulk density $1.1 \mathrm{~g} \cdot \mathrm{cm}^{-3}$, $\mathrm{pH} 7.1$, organic matter $1.8 \%$, total $\mathrm{N} 0.09 \%$, available phosphorus $21 \mathrm{mg} \cdot \mathrm{kg}^{-1}$, exchangeable potassium $3380 \mathrm{mg} \cdot \mathrm{kg}^{-1}$ with a textural analysis of $67 \%$ sand, $18 \%$ silt, and $15 \%$ clay).

Melon 'Proteo' was used as a scion and 'P360' (Cucurbita moschata Duchesne $x$ Cucurbita maxima Duchesne) was used as rootstock. In the previous trial (Expt. 1), the 'P360' rootstock exhibited high NUE. Treatments were defined by a factorial combination of three $\mathrm{N}$ fertilization levels $(0,60$, and $120 \mathrm{~kg} \cdot \mathrm{ha}^{-1}$ ) and two grafting combinations (ungrafted 'Proteo' and grafted 'Proteo' onto 'P360'). Each experimental unit consisted of three rows, $7 \mathrm{~m}$ in length, with 2-m row spacing and $1-\mathrm{m}$ in-row spacing containing 21 plants giving a theoretical plant population of 5000 plants/ha. The treatments were arranged in a randomized complete-block design with three replicates per treatment. Grafted ('Proteo'/'P360') and ungrafted ('Proeto') melon plants were transplanted on 29 May after a wheat crop. The 3-year rotations included wheat, melon, and processing tomato. Preplant fertilizer was broadcast $\left(\mathrm{kg} \cdot \mathrm{ha}^{-1} ; 90 \mathrm{P}\right.$ $120 \mathrm{~K}-15 \mathrm{Mg}$ ) and incorporated into the soil. Additional fertilizer $\left(\mathrm{kg} \cdot \mathrm{ha}^{-1} ; 80 \mathrm{~K}\right)$ was applied through the drip system using $\mathrm{K}_{2} \mathrm{SO}_{4}$. The $\mathrm{N}$ was applied as $\mathrm{NH}_{4} \mathrm{NO}_{3} 27 \%$ soluble fertilizer. The $\mathrm{N}$ was totally applied by fertigation starting $10 \mathrm{~d}$ after transplanting until $73 \mathrm{~d}$ later. The total amount of $\mathrm{N}$ was split into 10 weekly dressings and the percentage of the total $\mathrm{N}$ applied for each fertigation event was established according to Burt et al. (1998). Fertigations were performed by drip irrigation systems with in-line emitters located $0.30 \mathrm{~m}$ apart and an emitter flow rate of $3.4 \mathrm{~L} \cdot \mathrm{h}^{-1}$. Water $\mathrm{N}$ concentration was lower than $2 \mathrm{mg} \cdot \mathrm{L}^{-1}$; therefore, water was not considered a relevant source of this element.

Powdery mildew, caused by the fungi Erysiphe cichoracearum and Sphaerotheca fuliginea, was controlled by three foliar treatments of penconazole (Topas 10EC; Syngenta, Milano, Italy) + dinocap (Karathane FN; Dow Agrosciences, Bologna, Italy) at the labeled rate, whereas copper-based products (Coprantol WG; Syngenta, Milano, Italy) were used twice to control downy mildew (Pseudoperonospora cubensis); aphids and spider mites were controlled with one foliar treatment of imidacloprid (Confidor 200 SL; Bayer CropScience, Milano, Italy) and one foliar treatments of fenpiroximate (Miro; Bayer CropScience), respectively. Weeds were controlled with hand hoeing.

Measurements and analysis. The percentage of groundcover was estimated three times during the growing cycle $(40,55$, and $70 \mathrm{~d}$ 
after transplanting) by using digital camera images, which were taken vertically $2 \mathrm{~m}$ above the ground. At fruiting stage ( 8 July, $40 \mathrm{~d}$ after transplanting), the SPAD measurements were also recorded using the same procedure in as in Expt. 1.

Fully mature fruits were harvested from $10 \mathrm{Aug}$. (74 d after transplanting) to $18 \mathrm{Aug}$. (82 d after transplanting). Fruits that were cracked and badly misshapen were considered unmarketable. The number of fruits, mean fruit mass, and total and marketable yields were determined. The total and marketable yields were expressed in $\mathrm{t} \cdot \mathrm{ha}^{-1}$.

Six representative marketable fruits per treatment were analyzed for fruit quality parameters. Immediately after harvest, fruit shape index (SI), defined as the ratio of width to length, was measured. Pulp fruit firmness $\left(\mathrm{N} \cdot \mathrm{cm}^{-2}\right)$ was determined by removing three discs of the skin surface in the equatorial area and using a penetrometer (Bertuzzi FT 011; Brugherio, Milan, Italy) fitted with an 8-mm diameter round-head probe. The selected fruits were then cut into slices and separated into pulp, peel, and seeds and all fractions were weighed. From the liquid extract obtained from liquefying and filtering the mesocarp of each fruit, total soluble solids (TSS) contents in juice was determined by an Atago N1 refractometer (Atago Co. Ltd., Kobe, Japan) and expressed as ${ }^{\circ}$ Brix at $20{ }^{\circ} \mathrm{C}$. Acidity was determined by potentiometric titration with $0.1 \mathrm{M} \mathrm{NaOH}$ up to $\mathrm{pH} 8.1$ using $15 \mathrm{~mL}$ of juice. Results were expressed as percentage of citric acid in the juice. Fruit juice $\mathrm{pH}$ was also measured with a conductivity meter (HI- 991301; Hanna Instruments, Padova, Italy). Fruits were dried in a forcedair oven at $80{ }^{\circ} \mathrm{C}$ for $72 \mathrm{~h}$ and weighed to determine the fruit dry matter (DM). The fruit nitrate concentration was determined after aqueous extraction of $0.2 \mathrm{~g}$ of dried and ground fruit material in $10 \mathrm{~mL}$ of distilled water. A $100-\mu \mathrm{L}$ aliquot was taken and added to a solution containing $10 \%(\mathrm{w} / \mathrm{v})$ of salicylic acid dissolved in sulfuric acid and the $\mathrm{NO}_{3}{ }^{-}$ concentration was measured by spectrophotometry as described by Cataldo et al. (1975). The results were expressed as $\mathrm{mg} \cdot \mathrm{g}^{-1}$ of fruit FW. The total leaf $\mathrm{N}$ was also determined using the same methods as in Expt. 1.

At final harvest, 19 Aug. (83 d after transplanting), six plants per plot were separated into leaves, stems, and roots and their tissues were dried in a forced-air oven at $80^{\circ} \mathrm{C}$ for 72 $\mathrm{h}$ for biomass determination. Shoot dry biomass was equal to the sum of aerial vegetative plant parts (leaves + stems) and was expressed in $\mathrm{t} \cdot \mathrm{ha}^{-1}$. Harvest index (HI) was calculated as the ratio of DM partitioned into the fruit relative to the total plant biomass. The NUE (yield/ $\mathrm{N}$ application rate, $\mathrm{t} \cdot \mathrm{kg}^{-1}$ ), uptake efficiency (plant $\mathrm{N}$ content/ $\mathrm{N}$ application rate, $\left.\mathrm{kg} \cdot \mathrm{kg}^{-1}\right)$, and physiological use efficiency (yield/plant $\mathrm{N}$ content, $\mathrm{t} \cdot \mathrm{kg}^{-1}$ ) were also calculated.

Statistical analysis. Analysis of variance of the data were calculated using the software package, SPSS 10 for Windows (SAS Inc., Cary, NC). In the first experiment, orthogonal polynomial contrasts were used to compare $\mathrm{N}$ fertilization effects (Gomez and Gomez, 1983) on selected parameters. The parameters of the nonlinear equations in the first experiment ( $\alpha$ and $\beta$ ) were estimated by the "least squares" method of nonlinear regression (SigmaPlot 2002 for Windows Version 8.02; San Jose, $\mathrm{CA})$. In the second experiment, Duncan's multiple range test was performed at $P=0.05$ on each of the significant variables measured.

\section{Results}

Expt. 1. The relationships between the total shoot dry weight and the nitrate concentrations in the nutrient solution were best described by nonlinear functions for all grafting combinations (Fig. 1). All functions produced a coefficient of determination $\left(R^{2}\right)$ greater than 0.94 (Table 1). No significant differences among grafting combinations were recorded on $\alpha$ values (average $14.1 \mathrm{~g} / \mathrm{plant}$ ), whereas $\beta$ values were significantly influenced by grafting combinations with the lowest values observed in 'Proteo'/'Dinero', 'Proteo'/'Jador', and 'Proteo'/'P360' combinations (Table 1). Moreover, melon plants grafted onto 'Dinero', 'Jador', and 'P360' rootstocks needed 5.7, 5.2,


maximum SDW, whereas plants grafted onto 'PS1313' rootstock and the control treatment (ungrafted plants) needed 9.1 and $13.1 \mathrm{~mm}$ of $\mathrm{NO}_{3}$, respectively ( $\beta$ values in Table 1 ).

The total LA and the shoot $\mathrm{N}$ uptake at the end of the growing cycle were significantly affected by $\mathrm{N}$ fertilization and grafting combination with a $\mathrm{N} \times$ grafting interaction (Table 2). Total LA of ungrafted 'Proteo' and 'Proteo' grafted onto Cucurbita and C. melo rootstocks ('Proteo'/'Dinero', 'Proteo'/'Jador', 'Proteo'/ 'P360', and 'Proteo'/'PS1313') increased linearly and quadratically in response to an increase of the $\mathrm{N}$ concentration in the nutrient solution, respectively $(\mathrm{N} \times \mathrm{G}$ interaction, data not shown). Increasing the $\mathrm{N}$ concentration in the nutrient solution increased linearly the total shoot N uptake of ungrafted 'Proteo', 'Proteo'/'PS1313', and 'Proteo'/'P360' combinations, whereas a quadratically increasing was observed in 'Proteo'/'Dinero' and 'Proteo'/‘Jador' combinations $(\mathrm{N} \times \mathrm{G}$ interaction, data not shown).

The root-to-shoot ratio was significantly affected by the $\mathrm{N}$ concentration in the nutrient solution and by the grafting combination, whereas the SPAD index was only affected by the $\mathrm{N}$ concentration. Increasing the nitrate concentration in the nutrient solution from 0.5 to $15 \mathrm{~mm}$ caused linear and quadratical increases for the SPAD values, whereas an opposite trend was observed for the root-toshoot ratio (Table 2). Finally, the nitrate reductase (NR) activity was significantly affected by $\mathrm{N} \times$ grafting interaction with the highest NR activity observed in all treatments at $10 \mathrm{~mm}$ of $\mathrm{NO}_{3}{ }^{-}$(average $1.29 \mu \mathrm{mol} \mathrm{NO}{ }_{2}{ }^{-} \mathrm{g}$ of $\mathrm{FW} / \mathrm{h}$ ) followed by melon plants grafted onto both $C$. melo and pumpkin rootstocks grown at $2.5 \mathrm{~mm}$ of $\mathrm{NO}_{3}^{-}$(average $0.84 \mu \mathrm{mol}$ $\mathrm{NO}_{2}{ }^{-} / \mathrm{g}$ of $\mathrm{FW} / \mathrm{h}$ ), and finally on ungrafted melon plants supplied with a nutrient solution having $2.5 \mathrm{~mm}$ of $\mathrm{NO}_{3}{ }^{-}$(average $0.43 \mu \mathrm{mol}$ $\mathrm{NO}_{2}{ }^{-} / \mathrm{g}$ of $\mathrm{FW} / \mathrm{h}$ ) (Fig. 2).

Expt. 2. Forty $\mathrm{d}$ after transplanting, the percentage of groundcover was significantly $(P<0.05)$ affected by the $\mathrm{N}$ fertilization rate and grafting combination $(P<0.01)$ with no $\mathrm{N} \times$ grafting interaction, whereas the percentage of groundcover at 55 and $70 \mathrm{~d}$ after transplanting was only affected $(P<0.001)$ by the $\mathrm{N}$ fertilization rate (data not shown). Increasing the $\mathrm{N}$ fertilization rate from 0 to $120 \mathrm{~kg} \cdot \mathrm{ha}^{-1}$ increased the percentage of groundcover during the three sampling dates. Moreover, when averaged over $\mathrm{N}$ fertilization rates, the groundcover $40 \mathrm{~d}$ after transplanting was significantly higher by $56 \%$ in grafted (average $30.9 \%$ ) than in ungrafted plants (average 19.8\%).

Total and marketable yields, fruit number, and fruit mean mass were significantly affected by $\mathrm{N}$ fertilization rate and grafting combination with no significant $\mathrm{N} \times$ grafting interaction (Table 3). Moreover, the aboveground dry biomass and HI was highly influenced by $\mathrm{N}$ fertilization rates but not by grafting combinations; there was no $\mathrm{N} \times$ grafting interaction. Increasing the $\mathrm{N}$ fertilization rates from 0 to $120 \mathrm{~kg} \cdot \mathrm{ha}^{-1}$ increased the total and marketable yields of melon plants. The increase in total and marketable yields under high $\mathrm{N}$ fertilization levels (120 $\mathrm{kg} \cdot \mathrm{ha}^{-1}$ ) was attributed to an increase in the fruit mean mass and a change in the number of fruit per plant, whereas the higher total and marketable yields recorded in $60 \mathrm{~kg} \cdot \mathrm{ha}^{-1}$ of $\mathrm{N}$ compared with $0 \mathrm{~kg} \cdot \mathrm{ha}^{-1}$ of $\mathrm{N}$ was only attributed to the higher fruit number per plant. Moreover, when averaged over N fertilization levels, the marketable yield was significantly higher by $9 \%$ in grafted than in ungrafted plants. The low marketable yield in ungrafted plants was the result of both low mean fruit mass and low fruit number (Table $3)$. Increasing the $\mathrm{N}$ fertilization rates from 0 to $120 \mathrm{~kg} \cdot \mathrm{ha}^{-1}$ increased the above-ground dry biomass with the highest value recorded with $120 \mathrm{~kg} \cdot \mathrm{ha}^{-1}$ of $\mathrm{N}$ followed by plants receiving $60 \mathrm{~kg} \cdot \mathrm{ha}^{-1}$ of $\mathrm{N}$ and finally in the control treatment (Table 3), whereas an opposite trend was observed for the HI with the highest value recorded with plants receiving $0 \mathrm{~kg} \cdot \mathrm{ha}^{-1}$ of $\mathrm{N}$. The root dry biomass was only affected by grafting $(P<0.01)$ with the highest values observed in grafted (34.6 $\left.\mathrm{kg} \cdot \mathrm{ha}^{-1}\right)$ than ungrafted plants $\left(23.4 \mathrm{~kg} \cdot \mathrm{ha}^{-1}\right)$. Finally, the SPAD index was only affected by $\mathrm{N}$ levels $(P<0.01)$ with the highest values recorded with $120 \mathrm{~kg} \cdot \mathrm{ha}^{-1}$ of $\mathrm{N}$ (average 51).

No significant difference among treatments was observed for the percentage of seed (average 6.0\%), fruit firmness (average $14.6 \mathrm{~N} \cdot \mathrm{cm}^{-2}$ ), or the titratable acidity (average $0.09 \%$ ). The SI, the relative amounts of peel and pulp, and the nitrate concentration were significantly affected by the $\mathrm{N}$ fertilization rates but not by grafting and its interaction with $\mathrm{N}$ (Table 4). Increasing the $\mathrm{N}$ fertilization rates from 0 to $120 \mathrm{~kg} \cdot \mathrm{ha}^{-1}$ decreased the SI and the peel fraction and increased the pulp fraction and the nitrate concentration of melon fruits. Moreover, 


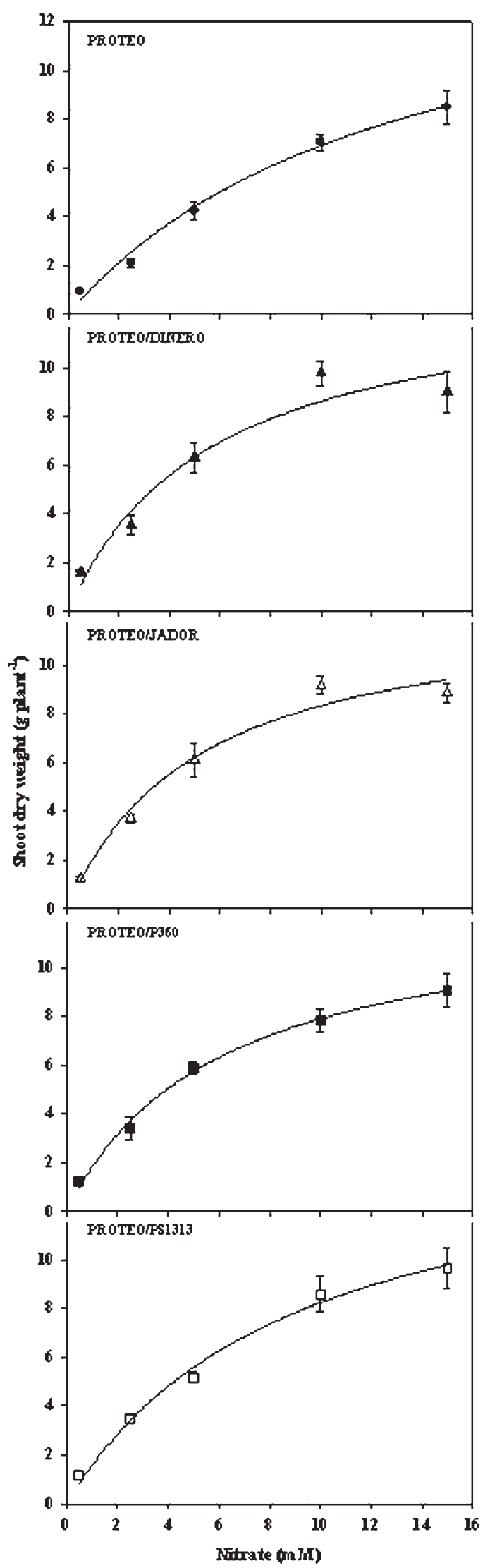

Fig. 1. Shoot dry weight response curves $[y=\alpha x /(\beta+x)]$ of different grafting combinations of melon grown over $45 \mathrm{~d}$ with different nitrate concentrations in the nutrient solution, in which $y$ indicates the shoot dry weight, $x$ is the nitrate concentration, $\alpha$ indicates maximum shoot dry weight, and $\beta$ represents the nitrate concentration at half-maximum shoot dry weight. Vertical bars indicate \pm SE of means; their absence indicates the size was less than the symbol. both $\mathrm{N}$ and grafting combination significantly affected the fruit DM and the TSS contents. The DM and TSS contents decreased in response to an increase in the $\mathrm{N}$ fertilization with the lowest values recorded on plants receiving $120 \mathrm{~kg} \cdot \mathrm{ha}^{-1}$ (Table 4). The DM and TSS contents in fruits harvested from ungrafted plants were significantly higher by $6.4 \%$ and $10.7 \%$, respectively, than these from grafted plants (Table 4).

The NUE and the $\mathrm{N}$ uptake efficiency were significantly affected by $\mathrm{N}$ fertilization rates and grafting combination with no significant $\mathrm{N} \times$ grafting interaction (Table 5). Moreover, $\mathrm{N}$ fertilization rates significantly affected the NUE (Table 5). When averaged over grafting combination, the NUE, $\mathrm{N}$ uptake efficiency, and $\mathrm{N}$ utilization efficiency were significantly higher by $81.6 \%, 60.4 \%$, and $13.3 \%$ when plants were supplied with 60 $\mathrm{kg} \cdot \mathrm{ha}^{-1}$ of $\mathrm{N}$ in comparison with those recorded with $120 \mathrm{~kg} \cdot \mathrm{ha}^{-1}$ of N. Finally, when averaged over $\mathrm{N}$ fertilization rates, the NUE and $\mathrm{N}$ uptake efficiency was significantly higher by $11.8 \%$ and $16.3 \%$, respectively, in grafted than in ungrafted plants (Table 5).

\section{Discussion}

Selection of commercial melon rootstocks with more advantageous nitrogen use efficiency traits. The description of productive behavior by SDW response curves in response to increasing the nitrate concentration (from 0.5 to $15 \mathrm{~mm}$ ) in the nutrient solution permits a more correct evaluation of NUE of the different melon grafting combinations by the estimate of $\alpha$ and $\beta$ indices. In agreement with Gourley et al. (1994) and Sorgonà et al. (2006), grafting combinations showed that the SDW response curves to increasing nitrate availability was best described by a nonlinear function, in which biomass increased with the increase in nitrate level in the nutrient solution up to a plateau that indicates the genetic potential of the different grafting combinations (Fig. 1). In the current study, $\alpha$ values were not significantly different, indicating that the five grafting combinations had equal genetic potential. The "equivalent yields" of genotypes when the nutrients are nonlimiting are essential to design the crop as nutrient-efficient or -inefficient (Gourley et al., 1994; Sorgonà et al., 2006). Assuming this criterion, the comparison of $\beta$ values of the grafting combinations with equal genetic potential makes it possible to define grafted plants ('Proteo'/'Dinero', 'Proteo'/'Jador', and 'Proteo'/'P360') (having the lower $\beta$ values) as being efficient in nitrate use compared with ungrafted plants (Table 1).

When the $\mathrm{N}$ fertilizer is applied in the form of $\mathrm{NO}_{3}{ }^{-}$, one of the major limitations of $\mathrm{NO}_{3}{ }^{-}$assimilation is the NR activity (Stitt, 1999; Tischner, 2001). In this study, no significant difference among treatments was observed for NR activity at high nitrate conditions (10 $\mathrm{mm})$, whereas under low nitrate conditions $(2.5 \mathrm{~mm})$, all grafted plants presented higher foliar values for this enzymatic activity than the ungrafted plants (Fig. 2). 
Table 1. Kinetic parameters of the shoot dry weight ( $\mathrm{g} / \mathrm{plant}$ ) response curve of different grafting combinations to nitrate concentration in the nutrient solution. ${ }^{\mathrm{z}}$

\begin{tabular}{lcccr}
\hline & \multicolumn{4}{c}{ Shoot dry wt response curve } \\
\cline { 2 - 5 } Grafting combination & $\alpha$ & $\beta$ & $R^{2}$ & SEE \\
\hline Proteo & $16.1 \mathrm{a}^{\mathrm{y}}$ & $13.2 \mathrm{a}$ & 0.996 & 0.242 \\
Proteo/Dinero & $13.5 \mathrm{a}$ & $5.7 \mathrm{~b}$ & 0.946 & 0.977 \\
Proteo/Jador & $12.6 \mathrm{a}$ & $5.2 \mathrm{~b}$ & 0.975 & 0.626 \\
Proteo/P360 & $12.7 \mathrm{a}$ & $6.1 \mathrm{~b}$ & 0.995 & 0.227 \\
Proteo/PS1313 & $15.7 \mathrm{a}$ & $9.1 \mathrm{ab}$ & 0.991 & 0.387 \\
\hline
\end{tabular}

${ }^{z}$ Coefficient of determination $\left(R^{2}\right)$ and SE of estimate (SEE) of the various response curves are also given.

${ }^{y}$ Means within columns separated using Duncan's multiple range test, $P=0.05$.

Table 2. Mean effects of nitrogen concentration and grafting combination on final leaf area (LA), root-toshoot ratio, SPAD index, and shoot nitrogen uptake of melon plants.

\begin{tabular}{|c|c|c|c|c|}
\hline Treatment & LA ( $\mathrm{cm}^{2} /$ plant $)$ & Root:shoot & SPAD & $\begin{array}{c}\text { Shoot N uptake } \\
\text { (mg/plant) }\end{array}$ \\
\hline \multicolumn{5}{|l|}{$\overline{\text { Nitrogen }\left(\mathrm{mM} \mathrm{NO}_{3}\right)}$} \\
\hline 0.5 & 135.2 & 0.64 & 28.4 & 20.5 \\
\hline 2.5 & 430.3 & 0.54 & 36.0 & 59.6 \\
\hline 5 & 911.5 & 0.35 & 39.5 & 144.7 \\
\hline 10 & 1617.7 & 0.26 & 42.9 & 290.5 \\
\hline 15 & 1567.5 & 0.22 & 46.8 & 347.1 \\
\hline \multicolumn{5}{|l|}{ Grafting } \\
\hline Proteo & $713.3 \mathrm{~b}^{\mathrm{z}}$ & $0.42 \mathrm{ab}$ & 38.0 & $150.9 \mathrm{~b}$ \\
\hline Proteo/Dinero & $1012.7 \mathrm{a}$ & $0.31 \mathrm{~b}$ & 39.5 & $173.9 \mathrm{a}$ \\
\hline Proteo/Jador & $981.4 \mathrm{a}$ & $0.35 \mathrm{ab}$ & 39.1 & $183.1 \mathrm{a}$ \\
\hline Proteo/P360 & $990.3 \mathrm{a}$ & $0.51 \mathrm{a}$ & 37.9 & $176.2 \mathrm{a}$ \\
\hline Proteo/PS1313 & $964.5 \mathrm{a}$ & $0.41 \mathrm{ab}$ & 39.1 & $188.3 \mathrm{a}$ \\
\hline \multicolumn{5}{|l|}{ Significance ${ }^{\mathrm{y}}$} \\
\hline Nitrogen $(\mathrm{N})$ & $* * *$ & $* * *$ & $* * *$ & $* * *$ \\
\hline Linear $\left(\mathrm{N}_{\mathrm{L}}\right)$ & $* *$ & $* *$ & $* * *$ & $* * *$ \\
\hline Quadratic $\left(\mathrm{N}_{\mathrm{Q}}\right)$ & $* * *$ & $* * *$ & $* *$ & $* *$ \\
\hline Grafting & $* * *$ & $*$ & NS & $* *$ \\
\hline $\mathrm{N} \times \mathrm{G}$ & $* * *$ & NS & NS & $*$ \\
\hline $\mathrm{N}_{\mathrm{L}} \times \mathrm{G}$ & $* *$ & NS & NS & $*$ \\
\hline $\mathrm{N}_{\mathrm{Q}} \times \mathrm{G}$ & $* *$ & NS & NS & $* *$ \\
\hline
\end{tabular}

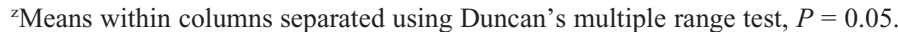

${ }_{\mathrm{L}}^{\mathrm{y}}=$ linear; $\mathrm{Q}=$ quadratic; $\mathrm{NS}, * * *, * * *$ nonsignificant or significant at $P<0.05,0.01$, and 0.001 , respectively.

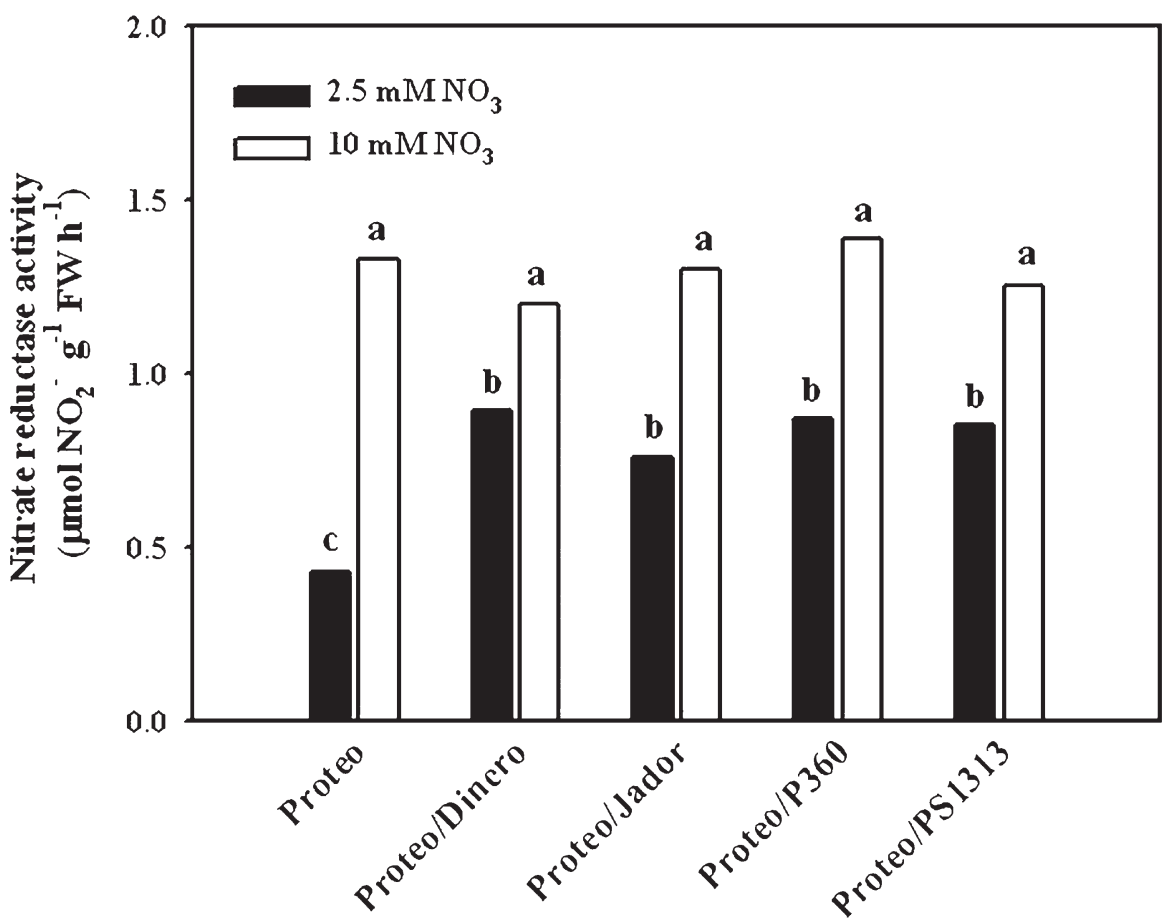

Fig. 2. Effects of nitrate concentration in the nutrient solution and grafting combination on nitrate reductase activity in melon leaves. Different letters indicate significant differences according to Duncan's test $(P=0.05)$.
According to Sivasankar and Oaks (1996), plants characterized by higher rates of $\mathrm{NO}_{3}{ }^{-}$ reduction show higher demand for this nutrient, increasing its uptake from the medium. Therefore, based on the results for NR activity under low nitrate conditions, grafted plants had potentially the greatest uptake efficiency and subsequent use of this nutrient for shoot biomass production. In contrast, in ungrafted plants, $\mathrm{NO}_{3}^{-}$concentration was lower, possibly owing to less uptake and translocation of $\mathrm{NO}_{3}{ }^{-}$toward the shoot, thereby reducing the presence of this anion in the leaves and in turn lowering NR activity. The more efficient NR activity in grafted plants might be associated with the effect of rootstock on the uptake of water and nutrients (Pulgar et al., 2000). Our results are in line with those of Ruiz and Romero (1999) and Ruiz et al. (2006), who observed that the use of certain rootstocks in melon and tobacco plants increased foliar $\mathrm{NO}_{3}{ }^{-}$reduction with respect to ungrafted plants. Moreover, the shoot $\mathrm{N}$ uptake has also been used as the determining parameter to select commercial melon rootstocks with more advantageous NUE traits. In the present work, the grafted plants presented the highest shoot $\mathrm{N}$ uptake (Table 2), confirming that melon plants grafted onto C. melo and pumpkins rootstocks efficiently used the $\mathrm{N}$ available in the medium.

In conclusion, according to the results of Expt. 1, NUE traits were improved by grafting melon plants onto commercial rootstocks given that in addition to increasing LA and shoot $\mathrm{N}$ uptake, grafted plants needed less $\mathrm{NO}_{3}{ }^{-}$in the nutrient solution to reach halfmaximum shoot dry weight. In addition, the higher NR activity of grafted plants under low nitrate conditions confirms that certain rootstocks have the potential to improve the NUE of grafted plants.

Grafting to improve nitrogen use efficiency traits of melon under open field conditions. It is well established that the increase of $\mathrm{N}$ up to a certain threshold increases yield up to a maximum level, but the further increase of $\mathrm{N}$ supply beyond the threshold affects yield negatively (Kirnak et al., 2005). In our case, increasing the $\mathrm{N}$ fertilization rate from 0 to 60 $\mathrm{kg} \cdot \mathrm{ha}^{-1}$ increased marketable yield by $21 \%$, whereas increasing the $\mathrm{N}$ rate from 60 to 120 $\mathrm{kg} \cdot \mathrm{ha}^{-1}$ increased melon production by only $10 \%$ (Table 3), indicating that the highest $\mathrm{N}$ applied rate was approaching the optimum $\mathrm{N}$ level. Our results are in line with those of Cabello et al. (2009), who observed under Mediterranean climatic conditions that the maximum melon yield $\left(42.9 \mathrm{t} \cdot \mathrm{ha}^{-1}\right)$ was obtained with no more than $112 \mathrm{~kg} \mathrm{~N} / \mathrm{ha}$.

When averaged over fertilization rates, the marketable yield was higher by $9 \%$ in grafted than in ungrafted plants (Table 3). The higher yields of melons from grafted plants observed in this study have been reported earlier (Ruiz et al., 1997; Ruiz and Romero, 1999). It was demonstrated that grafting directly affects plant yield (Neilsen and Kappel, 1996; Rivero et al., 2003) by interactions of some or all of the following processes: increase of water and nutrient uptake resulting from the vigorous 
Table 3. Mean effects of nitrogen fertilization rate and grafting combination on total yield (t.ha $\left.{ }^{-1}\right)$, marketable yield $\left(\mathrm{t} \cdot \mathrm{ha}^{-1}\right)$, fruit number (no./plant), fruit mean mass $(\mathrm{kg} /$ fruit), above-ground dry biomass $\left(\mathrm{t} \cdot \mathrm{ha}^{-1}\right)$, and harvest index (HI) of melon plants.

\begin{tabular}{|c|c|c|c|c|c|c|}
\hline \multirow[b]{2}{*}{ Treatments } & \multicolumn{2}{|c|}{ Yield } & \multicolumn{2}{|c|}{ Marketable fruit } & \multirow[b]{2}{*}{ Dry biomass } & \multirow[b]{2}{*}{$\mathrm{HI}$} \\
\hline & Total & Marketable & Number & Mean mass & & \\
\hline \multicolumn{7}{|c|}{$\overline{\text { Nitrogen rate }\left(\mathrm{kg} \cdot \mathrm{ha}^{-1}\right)}$} \\
\hline 0 & $34.4 \mathrm{c}^{\mathrm{z}}$ & $34.2 \mathrm{c}$ & $4.39 \mathrm{c}$ & $1.54 \mathrm{a}$ & $4.38 \mathrm{c}$ & $0.71 \mathrm{a}$ \\
\hline 60 & $41.4 \mathrm{~b}$ & $41.3 \mathrm{~b}$ & $5.26 \mathrm{~b}$ & $1.55 \mathrm{a}$ & $5.09 \mathrm{~b}$ & $0.67 \mathrm{ab}$ \\
\hline 120 & $45.7 \mathrm{a}$ & $45.5 \mathrm{a}$ & $6.01 \mathrm{a}$ & $1.49 \mathrm{~b}$ & $5.63 \mathrm{a}$ & $0.62 \mathrm{~b}$ \\
\hline \multicolumn{7}{|l|}{ Grafting } \\
\hline Proteo & $38.7 \mathrm{~b}$ & $38.6 \mathrm{~b}$ & $5.11 \mathrm{~b}$ & $1.47 \mathrm{~b}$ & 5.03 & 0.67 \\
\hline Proteo/P360 & $42.2 \mathrm{a}$ & $42.0 \mathrm{a}$ & $5.32 \mathrm{a}$ & $1.57 \mathrm{a}$ & 5.03 & 0.66 \\
\hline \multicolumn{7}{|l|}{ Significance } \\
\hline Nitrogen $(\mathrm{N})$ & $* * *$ & *** & $* * *$ & $* * *$ & ** & ** \\
\hline Grafting $(\mathrm{G})$ & ** & * & * & $*$ & NS & NS \\
\hline $\mathrm{N} \times \mathrm{G}$ & NS & NS & NS & NS & NS & NS \\
\hline
\end{tabular}

${ }^{\mathrm{z}}$ Means within columns separated using Duncan's multiple range test, $P=0.05$.

NS, $* * *, * * *$ Nonsignificant or significant at $P<0.05,0.01$, and 0.001 , respectively.

Table 4. Mean effects of nitrogen fertilization rate and grafting combination on shape index, the percentage of different fruit parts (peel, pulp, and seeds), fruit firmness, fruit dry matter (DM), total soluble solids (TSS) contents, fruit juice $\mathrm{pH}$, titratable acidity, and nitrate concentration of melon fruits.

\begin{tabular}{|c|c|c|c|c|c|c|c|c|c|c|}
\hline Treatment & $\begin{array}{l}\text { Shape } \\
\text { index }\end{array}$ & $\begin{array}{l}\text { Peel } \\
(\%)\end{array}$ & $\begin{array}{l}\text { Pulp } \\
(\%)\end{array}$ & $\begin{array}{l}\text { Seed } \\
(\%)\end{array}$ & $\begin{array}{l}\text { Firmness } \\
\left(\mathrm{N} \cdot \mathrm{cm}^{-2}\right)\end{array}$ & $\begin{array}{l}\mathrm{DM} \\
(\%)\end{array}$ & $\begin{array}{c}\text { TSS } \\
\left({ }^{\circ} \text { Brix }\right)\end{array}$ & $\mathrm{pH}$ & $\begin{array}{l}\text { TA } \\
(\%)\end{array}$ & $\begin{array}{c}\mathrm{NO}_{3} \\
\left(\mathrm{mg} \cdot \mathrm{kg}^{-1}\right)\end{array}$ \\
\hline \multicolumn{11}{|c|}{$\overline{\text { Nitrogen rate }\left(\mathrm{kg} \cdot \mathrm{ha}^{-1}\right)}$} \\
\hline 0 & $0.81 \mathrm{a}^{\mathrm{z}}$ & $34.7 \mathrm{a}$ & $59.7 \mathrm{~b}$ & 5.6 & 15.8 & $8.5 \mathrm{a}$ & $8.4 \mathrm{a}$ & 6.53 & 0.08 & $41.0 \mathrm{~b}$ \\
\hline 60 & $0.79 \mathrm{ab}$ & $32.1 \mathrm{ab}$ & $61.7 \mathrm{ab}$ & 6.3 & 15.1 & $8.1 \mathrm{ab}$ & $7.9 \mathrm{ab}$ & 6.48 & 0.09 & $53.6 \mathrm{ab}$ \\
\hline 120 & $0.77 \mathrm{~b}$ & $30.4 \mathrm{~b}$ & $63.3 \mathrm{a}$ & 6.4 & 13.0 & $7.7 \mathrm{~b}$ & $7.4 \mathrm{~b}$ & 6.40 & 0.09 & $56.1 \mathrm{a}$ \\
\hline \multicolumn{11}{|l|}{ Grafting } \\
\hline Proteo & 0.80 & 32.6 & 61.6 & 5.8 & 15.2 & $8.3 \mathrm{a}$ & $8.3 \mathrm{a}$ & $6.53 \mathrm{a}$ & 0.08 & 48.6 \\
\hline Proteo/P360 & 0.78 & 32.2 & 61.5 & 6.3 & 14.0 & $7.8 \mathrm{~b}$ & $7.5 \mathrm{~b}$ & $6.39 \mathrm{~b}$ & 0.09 & 51.8 \\
\hline \multicolumn{11}{|l|}{ Significance } \\
\hline Nitrogen $(\mathrm{N})$ & * & * & * & NS & NS & ** & ** & NS & NS & $* *$ \\
\hline Grafting (G) & NS & NS & NS & NS & NS & * & * & * & NS & NS \\
\hline $\mathrm{N} \times \mathrm{G}$ & NS & NS & NS & NS & NS & NS & NS & NS & NS & NS \\
\hline
\end{tabular}

${ }^{\mathrm{z}}$ Means within columns separated using Duncan's multiple range test, $P=0.05$.

Ns, *, **Nonsignificant or significant at $P<0.05$ and 0.01 , respectively.

Table 5. Mean effects of nitrogen fertilization rate and grafting combination on nitrogen use efficiency, nitrogen uptake efficiency, and nitrogen utilization efficiency of melon plants.

\begin{tabular}{lccc}
\hline Treatment & $\begin{array}{c}\mathrm{N} \text { use efficiency } \\
\left(\mathrm{t} \cdot \mathrm{kg}^{-1}\right)\end{array}$ & $\begin{array}{c}\mathrm{N} \text { uptake efficiency } \\
\left(\mathrm{kg}^{-1} \mathrm{~kg}^{-1}\right)\end{array}$ & $\begin{array}{c}\mathrm{N} \text { utilization } \\
\text { efficiency }\left(\mathrm{t} \cdot \mathrm{kg}^{-1}\right)\end{array}$ \\
\hline $\begin{array}{l}\text { Nitrogen rate }\left(\mathrm{kg} \cdot \mathrm{ha}^{-1}\right) \\
\quad 00\end{array}$ & $0.69 \mathrm{a}^{\mathrm{z}}$ & $1.38 \mathrm{a}$ & $0.51 \mathrm{a}$ \\
120 & $0.38 \mathrm{~b}$ & $0.86 \mathrm{~b}$ & $0.45 \mathrm{~b}$ \\
Grafting & & & \\
$\quad$ Proteo & $0.51 \mathrm{~b}$ & $1.04 \mathrm{~b}$ & 0.49 \\
$\quad$ Proteo/P360 & $0.57 \mathrm{a}$ & $1.21 \mathrm{a}$ & 0.47 \\
Significance & & & $*$ \\
$\quad$ Nitrogen $(\mathrm{N})$ & $* * *$ & $* *$ & $\mathrm{NS}$ \\
$\quad$ Grafting $(\mathrm{G})$ & $* *$ & $*$ & $\mathrm{NS}$ \\
$\mathrm{N} \times \mathrm{G}$ & $\mathrm{NS}$ & $\mathrm{NS}$ &
\end{tabular}

${ }^{\mathrm{z}}$ Means within columns separated using Duncan's multiple range test, $P=0.05$.

Ns, * **, ***Nonsignificant or significant at $P<0.05,0.01$, and 0.001 , respectively.

root system of the rootstock (Lee, 1994; Ruiz et al., 1997), enhanced production of endogenous hormones (Zijlstra et al., 1994), or enhancement of scion vigor (Leoni et al., 1990). The joint action of some or all of these processes could explain the higher yield in melon from grafted plants observed in the current study.

Both $\mathrm{N}$ fertilization rates and grafting combinations significantly affected the fruit quality parameters (Table 4). The $\mathrm{N}$ amount did not affect the fruit appearance (firmness) in accordance with a previous study on the effect of fertilization levels on melon fruit quality (Ferrante et al., 2008), whereas the nutritional qualities such as fruit DM and TSS contents were negatively affected by in- creased significantly. Many investigations have provided evidence that certain Cucurbita rootstocks may significantly deteriorate fruit quality (Lee, 1994; Lee and Oda, 2003). In the present study, nutritional qualities such as fruit DM and TSS contents of grafted melon were slightly inferior to those of ungrafted plants, whereas physical qualities such as SI and fruit firmness and the nitrate concentrations were equal to those of plants grown on their own roots. Similar results were previously reported on grafted melon plants by Colla et al. (2006b). This decrease in fruit quality does not represent a general phenomenon but depends on the specific scion-rootstock interaction and on the particular combination of growing conditions (Crinò et al., 2007).

The NUE and N uptake efficiency was significantly higher by $11.8 \%$ and $16.3 \%$, respectively, in grafted than in ungrafted plants, verifying our hypothesis that grafting melon plants onto pumpkin rootstock could improve NUE of the scion.

In conclusion, we found that the use of melon grafted on selected rootstock would represent a potential strategy for increasing yield and NUE and coping with soil fertility problems under "low-input" conditions.

\section{Literature Cited}

Ahmad, Z., M.A. Gill, and R.H. Qureshi. 2001. Genotypic variations of phosphorus utilization efficiency of crops. J. Plant Nutr. 24:11491171.

Arao, T., H. Takeda, and E. Nishihara. 2008. Reduction of cadmium translocation from roots to shoots in eggplant (Solanum melongena) by grafting onto Solanum torvum rootstock. Soil Sci. Plant Nutr. 54:555-559.

Baligar, V.C. and N.K. Fageria. 2001. Nutrient use efficiency in plants. Commun. Soil Sci. Plant Anal. 32:921-950.

Bremner, J.M. 1996. Total nitrogen, p. 1085-1121. In: Bingham, J.M. (Editor-in Chief). Methods of Soil Analysis. Part 3 Chemical Methods, SSSA Book Series: 5. Soil Science Society of America, Inc., and American Society of Agronomy Inc., Madison, WI.

Burt, C., K. O'Connor, and T. Ruehr. 1998. Fertigation, irrigation training and research center. California Polytechnic State University, San Luis Obispo, CA. p. 154-159.

Cabello, M.J., M.T. Castellanos, F. Romojaro, C. Martinez-Madrid, and F. Ribas. 2009. Yield and quality of melon grown under different irrigation and nitrogen rates. Agr. Water Manage. 96:866-874.

Cataldo, D.A., M. Haroon, L.E. Schrader, and V.L. Young. 1975. Rapid colorimetric determination of nitrate in plant tissue by nitration of salicylic acid. Commun. Soil Sci. Plant Anal. 6:71-80.

Colla, G., Y. Rouphael, M. Cardarelli, and E. Rea. 2006a. Effect of salinity on yield, fruit quality, leaf gas exchange, and mineral composition of grafted watermelon plants. HortScience 41 : 622-627.

Colla, G., Y. Rouphael, M. Cardarelli, D. Massa, A. Salerno, and E. Rea. 2006b. Yield, fruit quality and mineral composition of grafted melon plants grown under saline conditions. J. Hortic. Sci. Biotechnol. 81:146-152.

Colla, G., Y. Rouphael, M. Cardarelli, A. Salerno, and E. Rea. 2010. The effectiveness of grafting 
to improve alkalinity tolerance in watermelon. Environ. Exp. Bot. 68:283-291.

Crinò, P., C. Lo Bianco, Y. Rouphael, G. Colla, F. Saccardo, and A. Paratore. 2007. Evaluation of rootstock resistance to fusarium wilt and gummy stem blight and effect on yield and quality of grafted 'inodorus' melon. HortScience 42:521-525.

Dinnes, D.A., D.L. Karlen, D.B. Jaynes, T.C. Kaspar, J.L. Hatfield, T.S. Colvin, and C.A. Cambardella. 2002. Nitrogen management strategies to reduce nitrate leaching in tile-drained midwestern soils. Agron. J. 94:153-171.

Dong, H.H., Y.H. Niu, W.J. Li, and D.M. Zhang. 2008. Effects of cotton rootstock on endogenous cytokinins and abscisic acid in xylem sap and leaves in relation to leaf senescence. J. Expt. Bot. 59:1295-1304.

Edelstein, M., M. Ben-Hur, and Z. Plaut. 2007. Grafted melons with fresh or effluent water tolerate excess boron. J. Amer. Soc. Hort. Sci. 132:484-491.

Fageria, N.K. and V.C. Baligar. 2003. Methodology for evaluation of lowland rice genotypes for nitrogen use efficiency. J. Plant Nutr. 26: 1315-1335.

Ferrante, A., A. Spinardi, T. Maggiore, A. Testoni, and P.M. Gallina. 2008. Effect of nitrogen fertilization levels on melon fruit quality at the harvest time and during storage. J. Sci. Food Agr. 88:707-713.

Ferrario-Méry, S., M.C. Thibaud, T. Bettsche, M.H. Valadier, and C. Foyer. 1997. Modulation of carbon and nitrogen metabolism, and of nitrate reductase, in untransformed and transformed Nicotiana plumbaginifolia during $\mathrm{CO}_{2}$ enrichment of plants grown in pots and in hydroponic culture. Planta 202:510-521.

Gomez, K.A. and A.A. Gomez. 1983. Comparison between treatment means, p. 187-240. In: Gomez, K.A. and A.A. Gomez (eds.). Statistical procedures for agricultural research. 2nd Ed. John Wiley \& Sons, New York, NY.

Gourley, C.J.P., D.L. Allan, and M.P. Russelle. 1994. Plant nutrient efficiency: A comparison and suggested improvement. Plant Soil 158:29-37.

Kirnak, H., D. Higgs, C. Kaya, and I. Tas. 2005. Effects of irrigation and nitrogen rates on growth, yield, and quality of muskmelon in semiarid regions. J. Plant Nutr. 28:621-638.

Lafitte, H.R. and G.O. Edmeades. 1994. Improvement for tolerance to low soil-nitrogen in tropical maize. 1. Selection criteria. Field Crops Res. 39:1-14.

Lee, J.M. 1994. Cultivation of grafted vegetables. I. Current status, grafting methods, and benefits. HortScience 29:235-239.
Lee, J.M. and M. Oda. 2003. Grafting of herbaceous vegetables and ornamental crops. Hort. Rev. (Amer. Soc. Hort. Sci.) 28:61-87.

Leonardi, C. and F. Giuffrida. 2006. Variation of plant growth and macronutrient uptakein grafted tomatoes and eggplants on three different rootstocks. Eur. J. Hort. Sci. 71:97-101.

Leoni, S., R. Grudina, M. Cadinu, B. Madedu, and M.G. Carletti. 1990. The influence of four rootstocks on some melon hybrids and a cultivar in greenhouse. Acta Hort. 28:127-134.

Lynch, J.P. 1998. The role of nutrient-efficient crops in modern agriculture. J. Crop Prod. 1:241-264.

Machado, A.T. and M.S. Fernandes. 2001. Participatory maize breeding for low nitrogen tolerance. Euphytica 122:567-573.

Marschner, H., E.A. Kirkby, and I. Cakmak. 1996. Effect of mineral nutritional status on shoot-root partitioning of photoassimilates and cycling of mineral nutrients. J. Expt. Bot. 47:1255-1263.

Moll, R.H., E.J. Kamprath, and W.A. Jackson. 1982. Analysis and interpretation of factors which contribute to efficiency of nitrogen utilization. Agron. J. 74:562-564.

Neilsen, G. and F. Kappel. 1996. 'Bing' sweet cherry leaf nutrition is affected by rootstock. HortScience 31:1169-1172.

Otani, T. and N. Seike. 2007. Rootstock control of fruit dieldrin concentration in grafted cucumber (Cucumis sativus). J. Pestic. Sci. 32:235242.

Proietti, S., Y. Rouphael, G. Colla, M. Cardarelli, M. De Agazio, M. Zacchini, E. Rea, S. Moscatello, and A. Battistelli. 2008. Fruit yield of miniwatermelon as affected by grafting and irrigation regimes. J. Sci. Food Agr. 88:1107-1114.

Pulgar, G., G. Villora, D.A. Moreno, and L. Romero. 2000. Improving the mineral nutrition in grafted watermelon: Nitrogen metabolism. Biol. Plant. 43:607-609.

Rivero, R.M., J.M. Ruiz, E. Sanchez, and L. Romero. 2003. Does grafting provide tomato plants an advantage against $\mathrm{H}_{2} \mathrm{O}_{2}$ production under conditions of thermal shock? Physiol. Plant. 117:44-50.

Rodriguez, J.C., N.L. Shaw, D.J. Cantliffe, and Z. Karchi. 2005. Nitrogen fertilization scheduling of hydroponically grown 'Galia' muskmelon. Proc. Fla. State Hortic. Soc. 118:106-112.

Rouphael, Y., M. Cardarelli, G. Colla, and E. Rea. 2008a. Yield, mineral composition, water relations, and water use efficiency of grafted mini-watermelon plants under deficit irrigation. HortScience 43:730-736.

Rouphael, Y., M. Cardarelli, E. Rea, and G. Colla. 2008 b. Grafting of cucumber as a means to minimize copper toxicity. Environ. Exp. Bot. 63:49-58.

Ruiz, J.M., A. Belakbir, A. Lopez-Cantarero, and L. Romero. 1997. Leaf-macronutrient content and yield in grafted melon plants: A model to evaluate the influence of rootstock genotype. Sci. Hort. 71:227-234.

Ruiz, J.M., R.M. Rivero, L.M. Cervilla, R. Castellano, and L. Romero. 2006. Grafting to improve nitrogen-use efficiency traits in tobacco plants. J. Sci. Food Agr. 86:1014-1021.

Ruiz, J.M. and L. Romero. 1999. Nitrogen efficiency and metabolism in grafted melon plants. Sci. Hort. 81:113-123.

Savvas, D., D. Papastavrou, G. Ntasti, A. Ropokis, C. Olympios, H. Hartmann, and D. Schwarz. 2009. Interactive effects of grafting and manganese supply on growth, yield, and nutrient uptake by tomato. HortScience 44:19781982.

Sisson, V.A., T.W. Rufty, and R.E. Williamson. 1991. Nitrogen-use efficiency among flue-cured tobacco genotypes. Crop Sci. 31:1615-1620.

Sivasankar, S. and A. Oaks. 1996. Nitrate assimilation in higher plants: The effect of metabolites and light. Plant Physiol. Biochem. 34:609620.

Sorgonà, A., M.R. Abenavoli, P.G. Gringeri, and G. Cacco. 2006. A comparison of nitrogen use efficiency definitions in Citrus rootstocks. Sci. Hort. 109:389-393.

Stitt, M. 1999. Nitrate regulation of metabolism and growth. Curr. Opin. Plant Biol. 2:178-186.

Tischner, R. 2001. Nitrate uptake and reduction in higher and lower plants. Plant Cell Environ. 23:1005-1024.

Venema, J.H., B.E. Dijk, J.M. Bax, P.R. van Hasselt, and J.T.M. Elzenga. 2008. Grafting tomato (Solanum lycopersicum) onto the rootstock of a high-altitude accession of Solanum habrochaites improves suboptimal temperature tolerance. Environ. Exp. Bot. 63:359-367.

Yetisir, H., M.E. Çaliskan, S. Soylu, and M. Sakar. 2006. Some physiological and growth responses of watermelon [Citrullus lanatus (Thumb.) Matsum. and Nakai] grafted onto Lagenaria siceraria to flooding. Environ. Exp. Bot. 58:1-8.

Zijlstra, S., S.P.C. Groot, and J. Jansen. 1994. Genotypic variation of rootstocks for growth and production in cucumber. Possibilities for improving the root system by plant breeding. Sci. Hort. 56:195-196. 